\title{
The Role of the Youth's New Protest Movements in the January 25th Revolution
}

\author{
Yusery Ahmed Ezbawy
}

Abstract The January 25th uprisings were instigated by youth social protest movements which were organised through online social networks and that had the experience and capability of taking their activism from the virtual world to the real. $A$ number of factors enabled the youth to unify ranks before the uprisings through a strong inner circle, which was then able to mobilise the middle-class and poor through different nodes, all joining forces at key sites, and all bound by common demands for reform, which then culminated in the one unified call upon Mubarak's ousting. Thanks to the political errors of the government in its security handling of the situation, and strengthened by the signals from the military that they would not strike against the people, there was nothing stopping the snowball rolling.

\section{Introduction}

Many terms may be used to describe the January 25th revolution, but perhaps the most apt description is that it was a popular, civil revolution. In other words, it was a revolution from below, yet was neither populist nor anarchic. It involved people from different social, educational and religious backgrounds and superseded political, ideological and intellectual distinctions. It was a civil revolution because it successfully maintained its peaceful nature until achieving its principal goal: the ousting of President Mubarak. ${ }^{1}$

This article first presents a scoping of the youth protest groups that sparked the January 25th revolution and then discusses how these movements organised themselves. It then debates whether they represented social protest movements or unorganised social activists who were able to seize the spontaneity of the moment.

This study relied on extensive interviews with youth from different coalitions and movements who played a key role in organising the January 25th uprisings and what followed in the ensuing days and months. This is complemented by a literature review that looks into both social movement theory and the emerging scholarship on the January 25th revolution.

\section{The snowball effect}

If we examine closely how the revolution unfolded, we will discover that events were not preorchestrated, nor were the steps that were trodden pre-planned. Within the snowball, we saw ever widening layers of people being drawn in. There was a small bloc of politically conscious youth, the core, which was later dubbed the 'Facebook youth' and which began to expand to include a second, wider circle of apolitical youth who were motivated by their own pressing social problems. The politically active youth appealed to them by raising issues that struck a chord with their daily lives, such as the injustices they suffer as a consequence of rampant corruption. The third circle comprised members of the middle-class who were increasingly squeezed politically and economically and who joined in large numbers. The fourth circle comprised members from the marginalised who live on the fringes of society.

The demands of the youth organisers also took on a snowball effect. They started with specific grievances against the heavy security shackles on society and the opposition to inheritance of the presidency by Gamal Mubarak, and then the ceiling was raised to urge comprehensive political reform which then grew into one major demand: the ousting of Mubarak. 
What helped keep the snowball in momentum and in constant expansion were the reactions of the government in its handling of the protests through a fierce security response rather than a political settlement. None of the demands articulated by the youth activists and opposition were taken seriously: the government and National Democratic Party (NDP) officials repeatedly stated that Egypt was not Tunisia (a claim later repeated, mutatis mutandi, by leaders of Libya and Syria). When the government chose to adopt a political strategy of engagement after Tahrir Square had been occupied for days, it showed a complete disconnect with the level and scope of opposition in the Egyptian street. Its own strategy of engaging politically was discredited when it sent its own thugs on camels to brutally assault the hundreds of thousands of protestors stationed in Tahrir Square, commonly dubbed the 'Battle of the Camel', and thus convinced many more to join. Strengthened by the signals from the military that they would not strike against the people, the political errors of the regime and the masses flowing to public squares, there was nothing stopping the snowball from getting bigger.

Sidney Tarrow defined social movements as 'collective actions, based on common purposes and social solidarities, in sustained interaction with elites, opponents, and authorities' (Tarrow 1994). Doug McAdam posited three components vital to the understanding and analysis of social movements: the nature of the political opportunities arising from social and political changes in institutions of governance; the nature of the institutions and organisations developed by the social movement; and the cultural and intellectual beliefs and conceptions that bind supporters of the social movement (McAdam 1999). One can distinguish two types of movements based on the protest methods employed in Egypt: protest movements that rely on traditional means such as letter writing, petitions and boycotts, and new movements that have found a fertile space for activism in the internet by developing these traditional methods, creating e-mail campaigns to advertise their activities, and using the technology of new social networks to reach the largest number of people (Earl and Kimport 2008).

This article will argue that the uprisings were led by organised social protest movements that had planned for the January 25th uprisings, and which then through a snowball effect, took a momentum and life or their own.

\section{The social youth movements that sparked the revolution}

Since 2004, the Egyptian political scene has witnessed the emergence of several protest movements or political groups that have used demonstrations as a principal mode of action (Al-Banna 2011). Some, such as Kifaya (Enough), the National Campaign for Change, the Egyptian Campaign against Inheritance [of Presidency] known as Mayoukomsh, Journalists for Change, Lawyers for Change, the Democratic Engineers group and others, we would consider as elite-based groups that had limited representation from the youth.

The other groups were more diffuse in power arrangements and horizontal in structure and they were more inclusive vis-à-vis youth. They were essentially the ones that played the key role in organising the January 25 th uprisings. The most important protest movements that called for the January 25th revolution include: the 'We are all Khaled Said' Facebook page; the Rasd Network; the April 6th movement; Kifaya; the Justice and Freedom movement; the National Association for Change. The youth wings of the Muslim Brotherhood, the Democratic Front Party, the Tagammu', al-Ghad and al-Karama also played a role and, with the exception of the al-Ghad party, they all participated against the will of the party leadership. ${ }^{2}$ There follows a brief profile of the key organisers behind the January 25th uprisings.

\subsection{The April 6th youth movement}

This movement emerged within an extremely volatile environment characterised by a flaccid regime and the failure of political parties and protest movements such as Kifaya to allure youth to its ranks (Al-Sayyid 2008). In a bid to avoid security harassment, the youth turned to electronic space to engage, and it began to take on specific youth issues such as protesting against the rise in enrolment fees in the faculties of engineering and medicine in 2007. The April 6th group took on a public face in the third week of March 2008, when it successfully used mobile phones and the internet to call for a general strike on 6 April 2008, through the 'stay at home' campaign (Hilal 2009). Most of the youth are not affiliated to any one political party or force and 
have actively avoided adopting a specific ideology in order to preserve its internal diversity, according to its members. At the wake of the January 25th strike, it had over 70,000 online members.

\subsection{The Hashd movement}

This is the second youth protest movement to emerge after the April 6th movement. A radical movement that adopts a Leninist and Stalinist programme, it is a wing of the Revolutionary Socialists, which in early 2010, split into two factions: 'al-Hashd' and 'Socialist Renewal'. The prime cause of the schism was the sharp disagreement over whether organisation should precede action or vice-versa. Members of al-Hashd took part in the January 25th demonstration as individuals, but the organisation threw its weight behind the protest on 27 January.

\subsection{The Justice and Freedom movement}

Born on 21 July 2010, the movement had a strong street presence, organising its first demonstration on 23 July, followed by two more protests on 25 and 26 July. It is one of the strongest, most cohesive youth movements and has suffered no post-revolution internal schisms. It is a mix of liberals, leftists and large numbers of independent activists, which has helped to hold the movement together (Al-Qamash 2011). The goal of the movement is to avoid the errors of the Revolutionary Socialists and to be ideologically as inclusive as possible. For this reason, the name Justice and Freedom was adopted: it is based on the idea of freedom and democracy, in which all currents believe, and justice, a principle upon which no one disagrees.

\section{4 'We are all Khaled Said'}

This group was formed on Facebook after the death of Khaled Said on 6 June 2010 (Gad 2011). Said was tortured to death by police, sparking widespread protests that constituted an important prelude to the revolution. ${ }^{3}$ The case was not merely an instance of torture, but rather the assassination of a citizen who insisted on his right to know why security personnel were violating the rule of law (Al-Ash'al 2010). The 'We are all Khaled Said' group includes members of the coordinating committee of the youth branch of the National Association for Change, the Justice and Freedom movement, and April 6th (Al-Yawm al-Sabi' 2010). The youth members of the Facebook page come from different classes, but neither they nor the leaders have any specific ideology.

\subsection{The El Baradei Popular Campaign}

This campaign took shape even before the National Association for Change came into existence, in early February 2009 (Al-Shobaki 2010). A conflict split the members of the campaign on 6 April 2010 due to a disagreement over the movement's priorities. The leadership believed that street action should be calculated and should only be undertaken with the participation of prominent leaders like El Baradei in order to give it more political weight, protect campaign members and deter security pressure as much as possible. The other camp, most of them youth, adopted a different viewpoint summed up in the slogan, 'The Street is Ours'.

\subsection{El Baradei Support League}

The League grew out of the El Baradei Popular Campaign after the split in the ranks in April 2010. The League was formed and formally announced in June of that year after the two factions reached a dead end, particularly after League members objected to the decisionmaking policy within the campaign, which they believed was undemocratic and hierarchical. The opposing camp at that time argued that the time was not right to put all decisions before members because it may open the possibility of security infiltration. Many youth members of the campaign were detained while distributing flyers urging participation in the January 25th demonstrations, as these members did not have the experience of the April 6th movement or the political savvy of the Justice and Freedom movement in circumventing security apparatus.

\section{From lobbying to alliances and organisation within the square}

This section addresses the following questions: How was the call for revolution carried out? How were alliances managed between old and new protest movements growing out of the revolution? How did these entities deal with the lack of a unified leadership?

\subsection{How was the call to the revolution organised by social movements? And what was the relationship between them?}

Many young people carried the call for demonstrations on January 25th from the virtual to the tangible world, particularly those youth 
who belonged to social movements. Ahmad Mahir, a founder of the April 6th youth movement, suggested that their heavy online presence had a significant role in disseminating the call for revolution, particularly since the movement has branches in 24 governorates and operates in a decentralised fashion. On the day of the revolution, youth with the movement took to the streets before the appointed time, mobilising in popular areas before heading to major squares in various governorates. In Cairo, the April 6th movement's youth turned out in four groups and, surprisingly, began the protest in popular neighbourhoods (Mahir pers. comm. 2011). The April 6th movement distributed massive numbers of flyers - approximately half a million - and focused on informal, popular areas (Al-'Ishri pers. comm. 2011). The slogans used varied but the most effective were 'bread, freedom and social justice' and 'come down and join us before they finish us', and a number of other calls that spoke to people's violation of basic needs.

Youth groups on Facebook, most prominently the 'We are all Khaled Said' group and the Rasd Network organised demonstrations on 25 January to coincide with 'Police Day', a national holiday honouring an institution with a long and generally dark history. About 18 months prior to this, these movements had begun raising awareness in the provinces and encouraging protests against poor conditions in Egypt, the regime and police abuse. ${ }^{4}$

Moreover, what strengthened the force of January 25th was that the activists had successfully managed to secure the participation of the Ultras youth belonging to the two key sports teams in Egypt, Al Ahly and Zamalek. The Ultras were later to play a critical role in securing Tahrir Square against the security assaults and in particular, on the day of the Battle of the Camel. Abd el Moneim Imam, the coordinator of the National Campaign to support El Baradei, at governorate level, said that what made 25 January a possibility was that three core movements ('We are all Khaled Said', April 6th, and the National El Baradei Campaign) synchronised and coordinated their activities at a high level. Some young Muslim Brothers responded to the calls to take to the street on 25 January, despite the Guidance Bureau opposition to it. The secretariat of the group's student wing recommended that the Guidance
Bureau permit members of the group to take part regardless of participation by other members of the Muslim Brotherhood but the director of the student wing, Mahmud Abu Zayd, also a member of the Guidance Bureau, refused. Later, a number of young Brothers met with 'Isam al-'Iryan and reached a compromise, whereby the organisation would not endorse the January demonstrations, but any member of the organisation maintained the right to participate on an individual basis if he wished (Al-Qassas pers. comm. 2011).

The young Brothers established a closed Facebook page for Brotherhood youth, entitled 'Word of Truth', and all the young Brothers who wished to participate in the demonstration were invited to join. The group coordinated with other movements to make a strong showing on Arab League Street in Mohandseen. In order to be able to resist the security's ability to repress the demonstration it was agreed that the nucleus of the demonstration would set out from a popular neighbourhood near Arab League Street, Imbaba's Nahiya neighbourhood. The protest first toured this area and managed to pick up thousands of young people before heading to Arab League Street, with a force too big for security forces to disperse. They were joined by thousands more youths who were waiting in the street as a result of the publicly announced schedule.

Other demonstrations were arranged in popular areas on 26 and 27 January and to mobilise large numbers for 28 January, the Friday of Rage/Fury protests. After the Muslim Brotherhood announced they would participate on 28 January, officials in the group's administrative bureaus and local branches coordinated to inform members of the locations of the five different demonstrations after more than 20 fictitious locales had been announced on the 'We are all Khaled Said' Facebook page to mislead security. The demonstrations set out from five vital areas: the Pyramids area, Muhandisin, Dar al-Salam, Nasr City and Shubra, and managed to enter and occupy Tahrir Square. Coordination among all movements continued during the sit-in until the formation of the Coalition of Revolutionary Youth; the first body to call for a million-person protest (millioniyya) in Tahrir Square on Tuesday, 1 February. The Coalition of Revolutionary Youth was created in the square during the youth's occupation of Tahrir Square. 
After Mubarak's departure, some youths began to form new entities. Ahmad Mahir suggested that the Coalition of Revolutionary Youth was initially comprised of five protest movements, as well as political forces and independents, but was later expanded to include representatives of political parties, with each faction given two membership seats in the coalition. The young Brothers were a major part of that coalition (Al-Gawad pers. comm. 2011).

As for the Federation of Revolutionary Youth, it emerged from the womb of the revolution. Nevertheless, a great many of its members and supporters had belonged to protest groups before the revolution and joined the call for demonstrations, printed and distributed flyers and used Facebook to spread the appeal online (Hamid pers. comm. 2011). The El Baradei Popular Campaign and the El Baradei Support League issued the call for revolution largely on the internet and Facebook, in addition to organising meetings in the provinces, raising awareness on the street and drawing in activists during signature drives (Sulayman pers. comm. 2011).

The call for demonstrations on 25 January 2011 issued by the April 6th movement was different, as the movement urged all political forces to participate. While youth social forces responded immediately to the appeal, several political forces and parties, particularly major ones such as the Wafd, the Nasserists, the Tagammu' and the Muslim Brotherhood, preferred to wait and see: until, by 27 January, they were certain it was actually a revolution. These forces then seized the opportunity, joined up and started to speak of the movement as if they had created and struggled for it. In fact, these parties initially rejected the call for demonstrations and said that they would not take part on 25 January because it was a national holiday and thus inappropriate for a protest.

Discussing relations with other protest movements before the revolution, Muhammad al-Qassas, a former member of the Muslim Brotherhood and a member of the revolution's coalition says that the Brotherhood youth maintained good relations with their peers in other protest movements, such as April 6th and Justice and Freedom, nurtured through demonstrations, meetings, panel discussions, and campaigns organised in support of certain candidates during the 2010 People's Assembly elections, as well as over Facebook. This encouraged the young Brothers to engage with the calls to participate in the January 25th revolution and coordinate meetings of the various protest movements to determine locations for demonstrations, the itinerary and the starting time. Representatives of Brotherhood youths consistently took part in these meetings, and two or three meetings were convened, in which young Brothers were involved to coordinate actions and the slogans that would be used, as well as to agree on a set of demands acceptable to all (Al-Qassas pers. comm. 2011).

Abd el Moneim Imam said that the El Baradei Popular Campaign mobilised its supporters in 20 governorates via Facebook and the distribution of flyers. There was coordination between some movements in the provinces both before and during the revolution. For example, three movements ('We are all Khaled Said', April 6th, and the El Baradei Campaign) coordinated on Election Day in 2010 to 'make noise', directing people in the street or at home to honk their horns or bang on pots and pans. This successful experiment took place in 14 governorates. Before the January 25th demonstrations, the three movements coordinated efforts once again, to identify locations for the demonstrations and the meeting points in al-Mahalla, an industrial town; Cairo; Damanhur, a town in the Delta; Alexandria and Suez. In some provinces, Muslim Brotherhood youth were involved in the coordination, particularly in al-Mahalla; although some of the organisation's leaders objected that Sa'd alKatatni intervened to facilitate the coordination. Nevertheless on 28 January, the 'Friday of Rage', there was no coordination between forces and the people who took to the street exceeded the coordination capacities of the different protest movements. There were massive numbers of demonstrators wholly unexpected by the protest movements. Attempts at coordination after hundreds of thousands had gathered in Tahrir Square were focused on harnessing energies and dispensing advice to maintain the occupation. The square was managed (coordination and organisation attempts) from an operations room behind the main stage and speakers run by the Muslim Brotherhood. The room itself included members of the Muslim Brotherhood, the National Association for Change, the El Baradei Popular Campaign, some independent youth and 
some national figures from the left. Another operations room set up by Mamduh Hamza, a world-renowned architect who designed the Alexandria public library, involved the Coalition of Revolutionary Youth, members of new coalitions and April 6th. The political elite and prominent figures met in other locations, such as the clinic of Dr 'Abd al-Jalil Mustafa, where food distribution and other matters were organised (Imam pers. comm. 2011).

Despite various organisational attempts, there were disagreements between some new coalitions, particularly during the days of uprisings when negotiations with the regime were taking place. This, then, was a political, rather than organisational, dispute, and national leaders intervened to resolve it (Imam pers. comm. 2011). Another group of youth said that two weeks before the revolution, several meetings had been convened to coordinate a draft of consensual demands, ${ }^{5}$ particularly between the El Baradei Popular Campaign and April 6th. In the period before the January 25th uprisings, there was division among different movements; however, the 'We are all Khaled Said' page unified ranks who began to coordinate for the event together (Sulayman pers. comm. 2011).

With respect to the organisation of the square and relations between protest movements during the days of uprisings, Al-Qassas believes it is false to claim that any one faction was in charge of security in the square or shouldered the brunt of responsibilities in the period from 28 January to 11 February. Everyone worked with other parties and strove for coordination, to secure the square, establish the first broadcast system in the square and provide blankets, tents and food. This cooperation among young people was facilitated by the unified nature of the demands (Al-Qassas pers. comm. 2011). In order to coordinate efforts, the Coordinating Committee of the Masses of the Revolution was founded, which included most coalitions and entities that had been formed as of that moment, including the Coalition of Revolutionary Youth, the Revolution Council of Trustees, the National Association for Change and the Egyptian Revolutionary Coalition (Al-Gawad Muhammad pers. comm. 2011).

Shortly after the Coalition of Revolutionary Youth was formed, a state of chaos emerged and dozens of coalitions were founded. As a result, April 6th left the coalition in April 2011 and began engaging with other coalitions in accordance with the new reality; it no longer has any links with the Coalition of Revolutionary Youth (Mahir pers. comm. 2011). It is noteworthy that during the revolution, a youth union was created within Tahrir Square, and there was substantial cooperation between movements that had existed prior to the revolution and those that began to take shape in the square (Hamid pers. comm. 2011).

In order to understand what happened in the immediate aftermath of the outbreak of the revolution, we can map the path of protest movements over several, successive stages that ultimately led to the desired change (Salim 2011).

\section{First stage}

This stage showed the importance of a strong core advocating change and connecting through social media, especially YouTube and Facebook, with the goal of mobilising and attempting to convey the voice and image of the protest movement to the outside world. The success of this tool for social communication and mobilisation against the authorities encouraged social movements demanding change to take note. This space saw its broadest participation during and after 25 January.

\section{Second stage}

This stage showed the importance of choosing a time imbued with moral significance to successfully mobilise against the regime. Egyptians chose 25 January as the date of uprising to correspond with the national holiday for the police, who had brought corruption and torture to the Egyptian population. Concentration in one location was vital, not only for the continuation of the revolution, but for continued mobilisation against the regime. Tahrir Square became the Ground Zero for the protest movement, constantly attracting more demonstrators - and the demonstrators continued to stage millionperson protests.

\section{Third stage}

This stage showed the need to unite around one slogan for change and clear, specific demands. On 25 January political demands coalesced on one objective: the ousting of the entire regime. 


\section{Final stage}

This stage showed successful fusing of doctrinal and political contradictions into one mass to show the strength of the street against the political authorities. The Egyptian revolution succeeded not only in involving young people who were not political before the January 25 th movement, but also in dissolving the intellectual, doctrinal, and even religious boundaries separating various segments of the Egyptian people. This process of increasingly drawing in new segments of society and new forces in support of the revolution created an enabling environment in the face of the authorities' violent security approach and several incidents planned by forces that had an interest in thwarting the revolution and staging a counterrevolution. The solid core that led the revolution for change in Egypt was relatively small and could have been easily crushed if not for the engagement and rallying of the surrounding social environment that embraced the revolution. Gradually, the regime began to lose the street after various groups of regular citizens joined the protestors, as well as professional syndicates and trade unions, at which point the call for change became a genuine revolution.

The precise method of confrontation was active, peaceful resistance, not Gandhian passive resistance. This awareness is also underscored by the tactics used by the revolutionary youth, namely congregating in low-income areas and middle-class suburbs and then moving on to strategic positions in public squares, in front of ministries and other important governmental establishments.

\subsection{How did the new revolutionary movements organise and manage the coalitions in the absence of a unified revolutionary leadership?}

To answer this question, we can make use of actor network theory, which first emerged in the mid1980s in the work of Bruno Latour (1987) and Michel Callon (1986). This theory provides a theoretical framework to study collective technological-social processes. According to the theory, the actors themselves grow and develop within a network of relationships; they themselves are a set of networks able to engage and overlap with numerous other networks. In fact, we can see this process at work in the formation of different groups such as the 'We are all Khaled Said', April 6 th, and youth with the Democratic Front Party, the National Association for Change and the
Muslim Brotherhood. These young people translated the theory into practice by building new networks through a series of processes and joint actions (demonstrations). The theory posits that the links in the chain are related, making the network manageable. This means that the direct ties and relationships between young people and various youth groups facilitated the management of coalitions and coordination, compensating for the absence of a leadership. According to this theory, the new network binding the January 25th youth acquired internal force, cohesion, coherence (stability) and organisation (affinities) in the absence of leadership, and the actors were thus prevented from following their personal inclinations (to become strong). The new network recruited others for the network's goals, utilised the qualifications and motives of its actors, and increased their benefit and functional importance (Ritzer 2006).

Applying this theory to the January 25th revolution reveals that the members of various protest movements overcame the absence of leadership via stability and unity within their own movements during the revolution and via ties and coordination with the other movements. Thus, the January 25th revolution, sparked by groups of young people, was a leaderless revolution, joined immediately by large masses without a unified leadership. It was a revolution that was launched in a virtual space within a network - the internet - with all its new tools of communication: most importantly blogs, Facebook, and Twitter, and then moving into non-virtual society after the date and location had been set (Al-Sayyid 2011).

Clearly, the January 25th revolution, made by masses of people, did not have a defined leadership or project. It was thus natural that groupings and coalitions would take shape and compete to fill a general political vacuum. Because the Supreme Council of the Armed Forces (SCAF) was relatively hesitant and slow to make decisions during the days prior to the ousting of Mubarak, these groupings acquired greater significance, becoming pressure groups that had an effective impact on achieving important steps toward the demands of those who turned out on 25 January.

However, not all coalitions should be put in the same basket, insofar as they include authentic 
coalitions and interlopers with fictitious identities. These distinctions permit us to avoid generalising the term 'revolutionaries' and applying it to everyone. There are numerous questions about some of these coalitions and how much of a consensus they represent. Some have said that one person formed five different coalitions using different names, all of them revolutionary in nature. It is also not certain about claims that some apparatuses aligned to the former regime formed other coalitions to serve their aims. Because the square was open to all, it is entirely natural that anyone with legitimate or illegitimate interests would attempt to mark their presence with a coalition to express these interests or a tent pitched in the heart of the square (Huwaydi 2011).

During the revolution, no one can plausibly claim that Tahrir Square had a leadership directing or coordinating all the masses that came daily. In the early period of the revolution, the most pressing question was: What should be done? What is the next step? The answer from some activists was first that the occupation of the square constituted an important means of pressure that could not be ignored; thus, the occupation had to continue. Second, it was the people who had made the revolution and who would preserve it. That is, ultimately the decision would come from the masses (Yusuf 2011).

Muhammad al-Qassas believed a collective leadership took tangible form in the coalition. No one party had the right of veto, but rather everyone had the right to put forward their own vision. In fact, this vision was largely that of the party or protest movement represented by the member tasked with attending coalition meetings. For example, before any coalition member went to a meeting, he would poll the movement or entity that had authorised him to speak in its name. Al-Qassas also says that the lack of a leadership was an asset, not a disadvantage. It was for this reason that the revolution was described as a people's revolution; it had no leader and no person could claim a monopoly over it. Yet, the problem of the lack of leadership was that it required extra effort to coordinate among different factions that played a role in the revolution's success (Al-Qassas pers. comm. 2011). The Federation of Revolutionary Youth dealt with the lack of leadership by agreeing to a rotation of internal positions among members and the creation of an executive bureau to give voice to the coalition's policies pending internal elections under the group's bylaws, as well as creating an executive body in each governorate (Hamid pers. comm. 2011). From the first moments of the revolution, the Muslim Brotherhood youth were in constant contact with the group's Guidance Bureau, sending a delegation to maintain communication on 25 January and inform them of the details and arrangements (Al-Gawad pers. comm. 2011).

One segment of youth believed that one of the most fruitful outcomes and strengths of the revolution was that it did not have a unified leadership organising its affairs. It appears that young people felt they were capable of forging their own future without recourse to the elites, although they were consulted.

Another faction of young people believed there was no specific leadership of the January 25th revolution for several reasons. First, the opposition under the old regime had never agreed on a unified coordinating leadership. Second, no figure in Egypt had emerged capable of rallying people around him/her and there had been no charismatic public figure for some time (Al-Buhayri pers. comm. 2011). Third, operations in the square were based on trial and error (Sulayman pers. comm. 2011). Thus, some youth believed that the absence of a unified leadership was one of the major problems facing the revolution, as a result of which numerous attempts to coordinate various movements and forces in the square failed (Al-Rubi pers. comm. 2011). To overcome this problem, young people agreed on a voting mechanism to make decisions and resolve disputes on visions and viewpoints (Al-Ishri pers. comm. 2011). In contrast, some youth did not believe the lack of leadership was at all problematic, especially during the revolution, because the demands were largely unified in the square, summed up in the slogan 'Leave', demanding the fall of the regime. After the ousting of Mubarak however, problems began to emerge, particularly the issue of who possessed the right to speak for all revolutionary forces (Al-Khuli pers. comm. 2011).

\subsection{Do the young people represent protest movements or are they social activists?}

The January 25th revolution was described as a youth revolution because of the role played by 
youth forces in advocacy, preparation and mobilisation, as well as the broad participation by young people and the efforts of numerous youth protest movements in the years leading up to the revolution, which helped create a climate conducive to the revolution. Regarding the question of whether the young people who made the revolution were part of protest movements or unorganised social activities, young people who took part in the revolution were themselves divided, with three different viewpoints prominent. Some young people ${ }^{6}$ believed that the youth who made the revolution were social activists and that the protest movements, the Muslim Brotherhood and other youth forces only accounted for 20 per cent of the protestors at most, or 25 per cent during the Battle of the Camel, administered from a tent in the middle of Tahrir Square that maintained communication with all the various coalitions, particularly in the governorates. When communications were cut, some participants from the Qalyubiya governorate came to Tahrir Square on foot (Imam pers. comm. 2011). In the first millionman protest, on 1 February, it is estimated that the Muslim Brotherhood constituted roughly 10 per cent, while political activists constituted 5 per cent and various protest movements and parties another 5 per cent. This means that approximately 80 per cent of those in the square were non-politicised youth and people without a leader or overriding purpose, moved only by an Egyptian instinct for dignity and pride (Yusuf 2011: 97). This faction of youth believed that the coalitions formed during and after the revolution were dominated by members of protest movements and some independents, particularly the Coalition of Revolutionary Youth, which included representatives from organised protest movements like April 6th, the Justice and Freedom movement, and factions such as the Muslim Brotherhood youth. It also included independent political activists who did not belong to a specific party or political formation but were united by their dissatisfaction with the country's political and social conditions. This included the likes of Nasir 'Abd al-Hamid and 'Abd al-Rahman Faris. This faction of youth believed that the revolution was born in the womb of a generation that dreamed of change rather than reform. Some of them belonged to protest movements, while others operated within parties and others acted independently (AlQassas pers. comm. 2011).
The second camp of youth believed that those who organised and participated in the revolution were a mixture of young people, non-politicised social activists and young people who represent various political and social movements (Al-Rubi pers. comm. 2011), all of whom responded to the demonstration appeals and actively participated in the revolution. It was politicised youth who were the most prominent due to their experience and media relations, but many of them - indeed, the vast majority - were apolitical youth. Evidence supporting this shows that the largest number of youth who died in the uprisings were independent youth who were unaffiliated with any protest or partisan movement (Al-Gawad pers. comm. 2011).

The third camp believes that the revolution was sparked and organised by protest and sociopolitical movements that existed before the revolution (Al-Khuli pers. comm. 2011) and had an organisational structure on the ground and online. Young people with these protest movements largely shouldered the burden of calling for and making the revolution. Those who then joined were largely regular citizens who did not shoulder the same responsibility as protest movements (Sulayman pers. comm. 2011). Some young people note that given the lack of leadership and organisation in the revolution, a great many social activists who took part were organised spontaneously and instinctually, particularly when everyone felt the revolution was in danger (Hamid pers. comm. 2011).

In the view of this author, Egyptian youth do not possess a monopoly on the revolution, as all segments of the Egyptian people took part. Yet, youth were the fuel and engine of the revolution. There are other youth groups that have no direct links to political action, but they also participated in the events, with or without the consent of their leaders. This included, for example, Salafi students, Coptic youth and the Free Student Federation. Also prominent in the revolution were large groups of independent activists, such as Wael Ghonim, 'Abd al-Rahman Faris, Ahmad Duma and others.

Moreover, the January 25th revolution allowed Egyptian young people and activists outside the country to play a prominent role in the success of the revolution. When the authorities decided to cut Egypt off from the world in the early days of the revolution by suspending internet access and 
mobile phone lines to prevent the mobilisation of revolutionaries, Egyptian youth abroad

established a group on Facebook that monitored developments inside Egypt and reported them to the world. Much international and Arab media depended on the group for news of events in Egypt. The personal web pages of many of these young people were also transformed into news portals where stories and videos were posted, and participants discussed and exchanged views on the Egyptian revolution.

\section{Conclusion}

In sum, the January 25 th revolution was made by three major groups: (1) regular, non-politicised Egyptians, who were the overwhelming majority of the revolutionaries; (2) members of social movements and human rights activists; and (3) the army, which did not intervene to crush the demonstrators, but rather maintained its neutrality during the decisive 18 days. In line with actor network theory, the youth struggled to establish internal cohesion, overcome divisive inclinations and focus on organising through different nodes, which then took on the form of a network enjoying high levels of synchronisation. Through the nodes of the network there was mobilisation of a wider circle of people, made possible through the division of labour to expand outreach and then transforming them into pressure points. Such processes characterised the January 25 th youth agency within and outside Tahrir Square.

According to Gurr, political violence emerges over three stages. It begins with a sense of

\section{Notes}

1 For more details, see: www.alraynews.com/ Papers.aspx?id $=14071$

2 Many young people who were interviewed by the author agree on this, including Mabruk 'Abd al-Wahhab al-'Ishri, a member of April 6th and the Democratic Front; Sharif al-Rubi, the founder of the al-Ghad party and a member of April 6th; and Tariq al-Khuli, a member of April 6th.

3 For more details, see: www.egyrev25.com/?p=323

4 For more information on the causes of the January 25th revolution, see: www.egyrev25.com/ ?p $=323$ discontent, followed by attempts to forge this discontent into political practices. Finally, these practices are activated in the form of violence against the political system, for example during revolutions or general insurgency (Gurr 1970).

What happened in Egypt follows similar lines with the politicisation of discontent across time. This discontent quickly became an outright revolution in all governorates around Egypt, making it difficult for the security forces to engage with demonstrators or disperse them with force.

The slogans and ideas that circulated inside Tahrir Square stoked Egyptians' sense of identity and deep connection by employing symbols or slogans that encapsulated collective problems, fostered unity, or encouraged struggle against the existing regime. The revolutionaries used the theory of relative deprivation - which posits that there is greater potential for political violence coming from areas or spheres with a keen sense of relative deprivation, such as crowded, poor urban areas - to identify areas from which the revolution would set out. Some protest movements such as April 6th started the demonstrations from informal areas to mobilise supportive masses. This indeed worked, and most of these actions were spontaneous expressions of anger. This helps explain the heavy participation of some social sectors, such as the educated middle-class, in the revolution, as these groups consistently faced growing relative deprivation throughout Mubarak's rule.

5 The group included Tariq al-Khuli, a member of April 6th; 'Abd al-Wahhab al-'Ishri, a member of April 6th; Sharif al-Rubi, a founder of the al-Ghad party, and Ahmad Kamil, a member of Hamdin Sabbahi's presidential campaign.

6 Such as 'Abd al-Rahman Yusuf, Abd el Moneim Imam, Ahmad Kamil, Ahmad Mahir and many others. 


\section{References}

Al-Ash'al, A. (2010) 'More Serious than the Khaled Said Case' [in Arabic], al-Masry alYoum, 19 July

Al-Banna, G. (2011) 'The Trinity of the Revolutionary Leadership: Agree, and May God Have Mercy on You' [in Arabic], al-Masry al-Youm, 3 August

Al-Qamash, M. (2011) Protest Movements: A Transformation into Organizations or Political Parties? [in Arabic], Wasat Party website, 11 April, www.alwasatparty.com/article-13453.html (accessed 8 September 2011)

Al-Sayyid, Y. (2011) 'Global Echoes of the Egyptian Revolution' [in Arabic], al-Ahram, 17 February

Al-Sayyid, Y. (2008) 'Blogging and Bloggers: Virtual Space Versus Non-Virtual Society' [in Arabic], Arab Strategic Report 2007-08, Cairo: Ahram Center for Political and Strategic Studies: 13-32

Al-Shobaki, A. (2010) Parties, Movements, and Prospects for Change in Egypt, Carnegie Foundation, www.carnegieendowment.org/2010/05/20/ parties-movements-and-prospects-for-changein-egypt/48d (accessed 19 October 2011)

Al-Yawm al-Sabi' (2010) [Arabic daily newspaper], 9 July

Callon, M. (1986) 'The Sociology of an ActorNetwork: The Case of the Electric Vehicle', in M. Callon, J. Law and A. Rip (eds), Mapping the Dynamics of Science and Technology: Sociology of Science in the Real World, Houndmills: Macmillan

Earl, J. and Kimport, K. (2008) 'The Targets of Online Protest', Information, Communication and Society 11.4: 449-72
Gad, I. (ed.) (2011) 'Protest Movements 2009-10' [in Arabic], Arab Strategic Report 2010, Cairo: Ahram Center for Political and Strategic Studies: 477

Gurr, T. (1970) Why Men Rebel, New Jersey: Princeton University Press: 421

Hilal, A. (2009) 'Youth, the Internet, and Politics: Searching for the Future' [in Arabic], al-Ahram, 27 June 27: 10

Huwaydi, F. (2011) Crisis of Legitimacy in Egypt [in Arabic], www.dakahliaikhwan.com/ printarticle.php?id=9299 $($ accessed 19 October 2011)

Latour, B. (1987) Science in Action: How to Follow Scientists and Engineers through Society, Cambridge MA: Harvard University Press

McAdam, D. (1999) Political Process and the Development of Black Insurgency, 1930-1970, 2nd edn, Chicago: Chicago University Press: 6

Ritzer, G. (ed.) (2006) Encyclopedia of Social Theory [in Arabic], Vol. 1, Mustafa Khalaf 'Abd alJawad (transl.), 1st edn, Cairo: Supreme Council for Culture: 70

Salim, A. (2011) 'Impact of the January 25 Revolution on the Arab Region' [in Arabic], in 'Amr Hashim (ed.), The January 25 Revolution: Preliminary Reading and Future Perspective, 3rd edn, Cairo: Ahram Center for Political and Strategic Studies: 287-9

Tarrow, S. (1994) Power in Movement: Collective Action, Social Movements and Politics, 2nd edn, Cambridge: Cambridge University Press: 4

Yusuf, A. (2011) Diaries of the Revolution of the Patient [in Arabic], 1st edn, Cairo: Dar alSha'ir: 81 